\title{
Masayoshi MATsumoRI: A Constitutional-anthropological Study of the Inhabitants of the Valley of the Kumano River
}

\section{熊野川流域住民の体質人類学的研究}

\author{
日本医科大学鯶生学教室（指導 古尾芳堆教授）
}

松森正美

\section{まえがき}

日本人の起源は人類学, 考古学の発達に伴 つて漸次時代をさかのぼつている.即ち明治時 代には，日本人の祖先は弥生式時代人であり， 繩文式時代人は日本の先住民族にすぎず，現 代日本人と血のつながりはないといわれた。 しかしその後の研究により繩文式時代人と弥 生式時代人とは混淆しながら現代日本人が出 来上つたといわれる。元して他より来住した 弥生式時代人は多数であつたとも又ごく少数 であつたとるいわれている，何れにせよ日本 人の生成は多種類の混血によつて行われた事 は確かといえよう，乙かしこの民族のの混血 の度合は当然各地方によつて異つている事が 想像され，その度合をはかる事によつて我民 族生成の解明を試みる事が出来ると考兄られ る.この目的を以て古屋及びその一門はこの 数年来国内各地の土着住民の体質人類学的研 究を行つてきた。私もこの一環として和歌山 罧本宮町及び熊野川町を中心として地方住民 の測定を行つた。

本地方が何時頃から開発されたかははつき りしない。しかし前期繩文式土器が多数出土 している事, 更にこれらの遺跡から土器, 石 鉦, 石錘, 石斧, 硬玉製品, 人骨等が出土し て挌り，かなり古代から開発されていた事が らかがえる・これらの事を裏書するかの様に 神武天皇御東征の神話の中にも当地方が登場 している。即ち日本書記によれば神武天皇は 難波より大和に入ろうとした。しかし大和に
は長髄彦がいて神武天皇の 胆駒越えを許さな かつた。 天皇はそこで海路をたどつて熊野に いたり，そこから大和に入つた。熊野からの

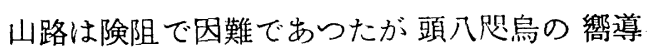
で菟田に達し，大和の征定を行つた。乞して この地方にいた兄猾, 弟猾, 八十困師, 兄磯 城，弟磯城などの土蜘蛛らも殺されたり，降 つたりしたという。この様に熊野地方に神武。 天皇御東征以前に先住していた民族として， 多数の土蜘蛛がいた事は歴史家の 承認すると ころである。吉野渓谷に占抛して後世まで残， 存した国栖は穴居の野民で山つて，土蜘蛛， 八掬脛と同種異族であるといわれている。

海は魚介に富み, 山には鳥獣豊か, 黒湖の 暖流をらけて気候温暖な当地方は狩㧩，漁筋 を主とする繩文式時代から新らしい水田耕作 を它の特色とする弥生式土器文化時代にかけ 遺跡は次第にその数をましてきている。更に 三世紀頃から古撌時代に入つてくる，元して こういらた古垻がみられるという事は，古垻 をつくる事の出来る大蒙族が 存在していた事 を示す。この前方後円式の古境の後円部の中 心に石棺があり，穴の中から耳飾，鏡等の装 身具や, 甲青, 刀剣, 鉃などの武器が出土し ている．棺の周囲からは，馬のかぶとや馬具 矛, 農具なども発見されている，以上の事か ら当時この地方が朝鮮や中国と密接な関係の あつた事が知られるのである。

当地方は地理的には和歌山県の南端に位し， 境を奈良, 三重と接している。紀伊半島の主 


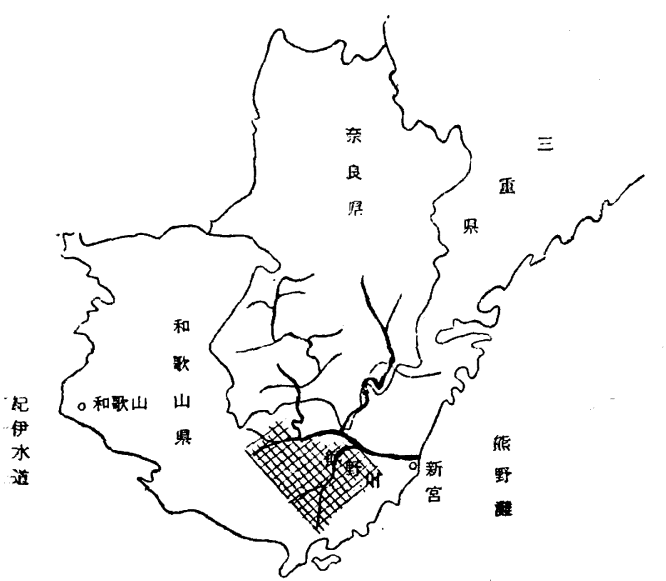

第 1 図测定地区

軸をなす紀伊山脈に 源を発する熊野川流域に 沼つた地方で第1 図に示すと招りである。

\section{I 計測条件と項目及び計測法}

計測を実施した地域は前記の加く熊野川上 流に位置するる 和歌山県本宮町及び 熊野川町で おる。

本計測の目的は，調査地区住民の正確な生 体測定を実施することにより，它の地域住民 の民族的特徵を把握するにある，従つて調查 対象としては，乞の土地に最近寄留したもの 及び一見して明かな体質異常者を除外するの 恃勿論であるが，更に本人が数代さかのぼつ て「地付の出」で岕ることを確かめて測定し た。被検者の年令は満 20 才より 45 才までの 男子で，元の人員は 528 名である.

体型比較の基準として使用した諸項目は体 質人類学的価値の高いものを選んだ。 即ち従 来, 古屋一門が体質人類学的見地から採用し ているもので，R. Martin 及びその他多くの 体質人類学者が使用している形質種から 12 型 質を直接に，2 型質を間接に 測定し，それら から 11 種の比率と指数を算出し計 25 項目に ついて比較分析を行つた。

下記に气の 25 項目をあげる。

測定項目比及び指数

○直接測定項目

(1) 身長 (7) 頭最大長
(2)耳珠高 (8) 頭最大幅

(3) 胸骨上椽高 (9) 最小前頭幅

(4) 肩峰高 (10) 制面骨弓幅

(5) 中指尖端高 (11) 下顎角幅

(6) 肩 幅 (12) 形態顔面高

○間接測定項目

(13) 耳頭高 $=$ 身長 $-耳$ 耳珠高

(44) 全上肢長 $=$ 肩峰高一中指尖端高 ○比及び指数

(15) 比上肢長 $=\frac{\text { 全上肢長 }}{\text { 身 長 }} \times 100$

(16) 比肩幅 $=\frac{\text { 肩幅 }}{\text { 身長 }} \times 100$

(17) 比頭長 $=\frac{\text { 頭最大長 }}{\text { 長 }} \times 100$

(18) 頭長幅指数 $=\frac{\text { 頭最大幅 }}{\text { 頭最大長 }} \times 100$

(19) 頭長耳頭高指数 $=\frac{\text { 耳頭高 }}{\text { 頭最大長 }} \times 100$

(20) 頭幅耳頭高指数 $=\frac{\text { 耳頭高 }}{\text { 頭最大幅 }} \times 100$

(21) 頭幅前頭幅指数 $=\frac{\text { 最小前頭幅 }}{\text { 頭最大幅 }} \times 100$

(22) 頭幅顴骨弓幅指数 $=\frac{\text { 顧骨弓幅 }}{\text { 頭最大幅 }} \times 100$

(23) 顴骨弓幅前頭幅指数 $=\frac{\text { 最小前頭幅 }}{\text { 制雱骨弓幅 }} \times 100$

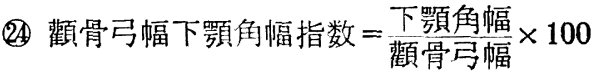

(25) 形態顔面指数 $=\frac{\text { 形態顔面高 }}{\text { 顧骨弓幅 }} \times 100$

本論文に括ける数值の取り扱い法及び計算 法は古屋の著書によつた。そのうち主な記号 及び計算法は次の通りで㐫る。

(1) 人 員 $\mathrm{N}$

(2) 算術平均 $\mathrm{M}$

(3) 標準偏差 $\sigma$

(4) 変異倸教 $\mathrm{V}$

(5) $\mathrm{M}, \sigma, \mathrm{V}$ の平均誤差は，そ礼ぞれ $\mathrm{m}$, $\mathrm{m} \sigma, \mathrm{mV}$

(6) 型差 (T.D) 及びその平均誤差 $\mathrm{m}$ (T.D)

$$
\begin{aligned}
\mathrm{T} . \mathrm{D} \pm \mathrm{m}(\mathrm{T} . \mathrm{D}) & =10\left(\frac{1}{\sigma_{1}}+\frac{1}{\sigma_{2}}\right)\left(\mathrm{M}_{1} \sim \mathrm{M}_{2}\right) \\
& \pm 10\left(\frac{1}{\sigma_{1}}+\frac{1}{\sigma_{2}}\right) \sqrt{\mathrm{m}_{1}^{2}+\mathrm{m}_{2}^{2}}
\end{aligned}
$$

(7) 平均型差 (M.T.D.) 及びその平均誤差 m (M.T.D) 


$$
\begin{aligned}
M \cdot T \cdot D \pm m(M . T . D) & =\frac{\Sigma\left(\frac{20}{V_{1}+V_{2}}\left(\frac{1}{\sigma_{1}}+\frac{1}{\sigma_{2}}\right)\left(M_{1} \sim M_{2}\right)\right)}{\Sigma\left(\frac{2}{V_{1}+V_{2}}\right)} \\
& \pm \frac{\Sigma\left(\frac{20}{V_{1}+V_{2}}\left(\frac{1}{\sigma_{1}}+\frac{1}{\sigma_{2}}\right) v^{\prime} m_{1}^{2}+m_{2}^{2}\right.}{\Sigma\left(\frac{2}{V_{1}+V_{2}}\right)}
\end{aligned}
$$

\section{II 軀斡四肢に関する研究成樍}

軀幹四肢に関する 研究成績を第一表に示し た。穴のうち特に身長，上肢長，比上肢長に ついて検討を加党た。

(1) 身 長

第 1 表 軀幹四肢の計測及び指数值

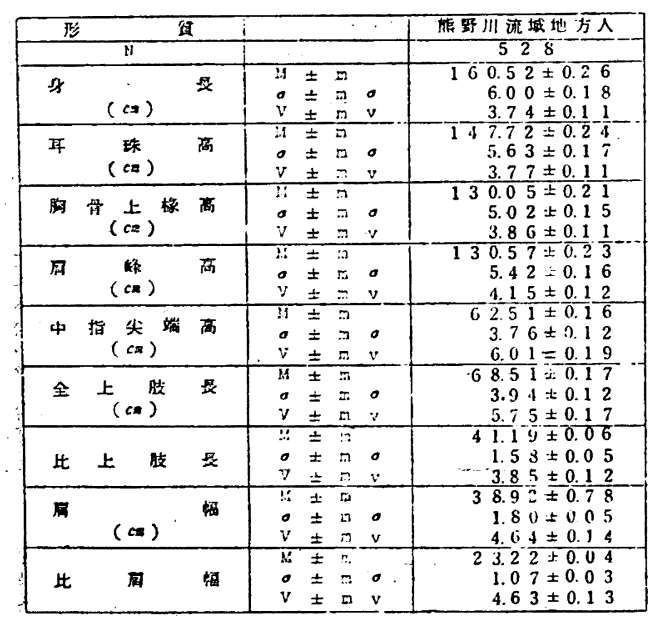

\begin{tabular}{|c|c|c|c|c|c|c|}
\hline & $\begin{array}{c}\text { 茜 小 } \\
130 \sim \\
149.9\end{array}$ & $\begin{array}{c}150 \\
150 \sim \\
159.9\end{array}$ & $\begin{array}{c}\text { 中ळ下 } \\
160 \sim \\
163.9\end{array}$ & $\begin{array}{c}4 \\
164 \sim \\
166.9\end{array}$ & $\begin{array}{l}\text { 中0上 } \\
167 \sim \\
169.9\end{array}$ & $\begin{array}{c}\text { 离 } \\
170 \sim \\
179.9 \\
\end{array}$ \\
\hline 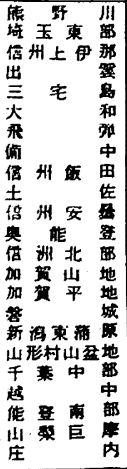 & $\begin{array}{ll}3.9 & 8 \\
3.8 & 0 \\
1.8 & 0 \\
2.5 & 3 \\
4.0 & 0 \\
0.5 & 5 \\
4.1 & 1 \\
2.4 & 2 \\
1.0 & 0 \\
0.0 & 0 \\
1.7 & 0 \\
5.5 & 2 \\
0.5 & 0 \\
3.8 & 9 \\
3.0 & 1 \\
1.8 & 9 \\
3.9 & 9 \\
4.1 & 6 \\
0.5 & 5 \\
3.8 & 8 \\
4.1 & 3 \\
5.5 & 3 \\
3.5 & 9\end{array}$ & $\begin{array}{llll}4.2 .2 & 3 \\
4 & 0.1 & 1 \\
3 & 9.0 & 0 \\
4 & 1.8 & 8 \\
3 & 2.8 & 0 \\
3 & 5.9 & 8 \\
5 & 7.7 & 8 \\
3 & 6.1 & 9 \\
3 & 3.5 & 8 \\
4 & 2.0 & 0 \\
3 & 6.4 & 9 \\
5 & 2.1 & 4 \\
2 & 6.4 & 1 \\
5 & 1.1 & 1 \\
4 & 4.1 & 5 \\
4 & 8.6 & 7 \\
5 & 6.3 & 3 \\
4 & 9.4 & 4 \\
3 & 2.2 & 9 \\
6 & 0.0 & 0 \\
4 & 8.3 & 2 \\
4 & 2.2 & 9 \\
4 & 2.5 & 8\end{array}$ & $\begin{array}{lll}2 & 7.0 & 8 \\
2 & 8.8 & 2 \\
2 & 8.8 & 0 \\
2 & 6.3 & 3 \\
3 & 1.2 & 0 \\
2 & 8.7 & 3 \\
2 & 1.9 & 2 \\
2 & 9.4 & 0 \\
2 & 5.5 & 0 \\
3 & 3.3 & 3 \\
2 & 9.4 & 9 \\
2 & 3.9 & 7 \\
2 & 9.9 & 1 \\
2 & 7.2 & 2 \\
2 & 7.5 & 4 \\
2 & 4.8 & 1 \\
2 & 2.5 & 3 \\
2 & 6.0 & 8 \\
2 & 8.2 & 6 \\
2 & 1.6 & 6 \\
2 & 6.8 & 6 \\
2 & 7.2 & 7 \\
2 & 9.8 & 5\end{array}$ & $\begin{array}{lll}1 & 3.9 & 2 \\
1 & 5.2 & 1 \\
1 & 5.0 & 0 \\
1 & 5.6 & 1 \\
1 & 7.6 & 0 \\
1 & 6.5 & 0 \\
& 9.9 & 6 \\
1 & 6.4 & 8 \\
1 & 8.5 & 0 \\
1 & 4.6 & 7 \\
1 & 7.5 & 8 \\
1 & 1.2 & 9 \\
1 & 9.7 & 6 \\
1 & 1.3 & 9 \\
1 & 4.4 & 0 \\
1 & 2.8 & 8 \\
1 & 2.4 & 4 \\
1 & 2.3 & 2 \\
1 & 9.0 & 8 \\
& 7.7 & 7 \\
1 & 0.7 & 9 \\
1 & 4.6 & 3 \\
1 & 3.7 & 0\end{array}$ & $\begin{array}{rl}7.8 & 6 \\
7.1 & 7 \\
11.4 & 0 \\
8.2 & 4 \\
8.8 & 0 \\
10.8 & 4 \\
5.1 & 1 \\
9.5 & 3 \\
15.0 & 0 \\
8.6 & 7 \\
9.0 & 7 \\
3.9 & 6 \\
14.28 \\
3.89 \\
7.3 & 8 \\
7.2 & 1 \\
2.82 & 2 \\
4.4 & 8 \\
13.2 & 1 \\
3.88 & 8 \\
6.9 & 2 \\
7.5 & 1 \\
7.1 & 8\end{array}$ & 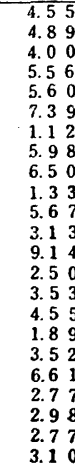 \\
\hline
\end{tabular}

第2表 身長分類表
第3表 身長に於ける熊野川流域地方

\begin{tabular}{|c|c|c|c|}
\hline \multirow{2}{*}{ 各地 人 } & \multirow{2}{*}{$\mathrm{K}_{2}$} & \multicolumn{2}{|c|}{ 能野川流城地方人 $160.52 \pm 0.26$} \\
\hline & & $M_{1} \sim u_{x}$ & T.D. $\pm \operatorname{mon}(\mathrm{T}, \mathrm{D})$, \\
\hline 塔 玉 束 部 & 160.44 & 0.08 & $0.27 \pm 0.15$ \\
\hline 光手下閉 争 & 160.75 & 0.23 & $0.79=0.12$ \\
\hline 贺设平地 & 160.28 & 0.24 & $0.83 \pm 0.09$ \\
\hline & 160.17 & 0.35 & $0.21 \pm 0.12$ \\
\hline 庄 & 160.16 & 0.36 & $1.24 \pm 0.11$ \\
\hline 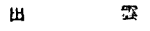 & 160.93 & 0.41 & $1.40 \pm 0.10$ \\
\hline$\psi$ & 160.93 & 0.41 & $1.41 \pm 0.12$ \\
\hline 立 & 160.00 & $0.5 \%$ & $1.79 \pm 0.12$ \\
\hline 切 蛝 平 野 & 161.24 & 0.72 & $2.41=0.13$ \\
\hline 三毛 & 161.29 & $0.7 \tau$ & $2.66 \pm 0.19$ \\
\hline 上 菬 & 159.77 & 0.75 & $2.67 \pm 0.12$ \\
\hline 信州上伊动 & 161.29 & 0.77 & $2.74 \pm 0.13$ \\
\hline 能 登 南 部 & 159.68 & 0.84 & $2.90 \pm 0.10$ \\
\hline 山形村山叠地 & 159.54 & 0.98 & $3.39 \pm 0.11$ \\
\hline 巨 & 159.50 & 1.02 & $3.63 \pm 0.14$ \\
\hline 岩 代 鰠 & 159.45 & 1.07 & $3.8 Q \pm 0.11$ \\
\hline 白 & 159.44 & 1.08 & $3.84 \pm 0.21$ \\
\hline 息 & 161.68 & 1.16 & $3.95 \pm 0.12$ \\
\hline 俉州安 & 161.65 & 1.13 & $4.02 \pm 0.14$ \\
\hline 甲 & 159.37 & 1.15 & $4.32 \pm 0.10$ \\
\hline 加贺山地 & 159.24 & 1.28 & $4.55 \pm 0.13$ \\
\hline 大 & 161.95 & 1.43 & $4.96 \pm 0.10$ \\
\hline$九$ & 159.02 & 1.50 & $5.19 \pm 0.11$ \\
\hline 海 & 158.96 & 1.56 & $5.24 \pm 0.12$ \\
\hline 要 & 162.03 & 1.51 & $5.37 \pm 0.20$ \\
\hline 向 & 158.99 & 1.53 & $5.44 \pm 0.10$ \\
\hline 楚 能 登 & 158.94 & 1.58 & $5.46 \pm 0.10$ \\
\hline 北海通 フィヌ & 159.02 & 1.50 & $5.71 \pm 0.17$ \\
\hline 算 强 & 158.66 & 1.86 & $6.62 \pm 0.11$ \\
\hline 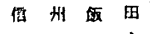 & 162.39 & 1.87 & $6.65 \pm 0.16$ \\
\hline 趋中（奶台） & 158.50 & 202 & $7.19 \pm 0.13$ \\
\hline 千 莱 中 部 & 162.49 & 1.97 & $7.21 \pm 0.12$ \\
\hline 鸹中（明迩） & 158.41 & 2.11 & $7.51 \pm 0.16$ \\
\hline E. 宗 & 162.29 & 1.77 & $7.54 \pm 0.19$ \\
\hline 新泹厤 原 & 158.28 & 2.24 & $7.97 \pm 0.12$ \\
\hline 北㔖公 州 & 163.20 & 2.68 & $9.80=0.12$ \\
\hline 因嵒 & 163.40 & 2.88 & $10.25 \pm 0.12$ \\
\hline
\end{tabular}
と他地方の型差

(1) 身 長

身長は各種の 身体測定に於て計測さ れ，人種形質の一指標として重要視され ているが，乞れは安定性に乏しく，生活 環境例えば栄養, 労働, 体育などの影響 によつて, 徐々に气の值が変動すること は衆知のことである。しかし，厹れは環 境の改善によつて無限に伸長するもので 
はなく，やはり艺の種族としての一定の限界 があるようである。そこに身長測定の人種的 意義を生ずるわけである，また，兮の変異係

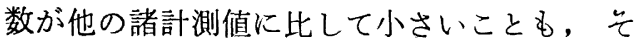
の価值が認められる理由の一つである。

本地方人の平均身長は $160.52 \pm 0.26 \mathrm{~cm}$ で あり，Martin の身長分類によつて穴の分布を みると第 2 表の如くで， その平均值は「中の 下」に属し，「甚小」及び「小」に属するもの を合わせるこ半数近くを占めている。艺して， その分布状況は埼互東部, 全庄内, 出雲の諸 地方と近似している．古屋により修正された 型差公式により，身長の型差を算出し，他地 方人と比較した結果を第 3 表に示した。本地 方人は埼玉東部, 岩手下閉伊, 加賀山地, 磐 城の諸地方と近親度が大であり，因幡，北部 信州, 新潟蒲原等とは親近度が小であること が分る。

（2）全上肢長

全上肢長は肩峰高より中指尖端高を引いた 間接計測值で㟔る。本地方人の艺れは平均值 68.51士0.17を示した。

(3) 比上肢長

比上肢長は身長に対する 全上肢長の 比を示 すもので比較的に変異係数が 小さいので人種 学的測定に扔いて重要のものとされている.

第4表 上肢分類表

\begin{tabular}{|c|c|c|c|c|c|c|}
\hline 地方 & & 分 & 顆 & 垁 $\begin{array}{c}\text { 䑀 } \\
\sim 42.9\end{array}$ & $\begin{array}{l}\text { 中 } \quad \text { 趽 } \\
43.0 \sim 44.9\end{array}$ & $\begin{array}{l}\text { 辰 } \\
45.0\end{array}$ \\
\hline 䋨 & & 野 & 川 & 63.15 & 29.52 & 7.33 \\
\hline 两 & & 千 & 楥 & 58.42 & 36.04 & 5.54 \\
\hline 生 & & & 内 & 10.77 & 42.74 , & 46.49 \\
\hline 岩 & 代 & 䛚 & 海 & 18.88 & 51.93 & 29.19 \\
\hline 倍 & H & 上争 & 那 & 25.00 & 58.50 & 16.50 \\
\hline$\equiv$ & & 宅 & Lis & 16.00 & 64.80 & 19.20 \\
\hline 八 & & 文 & $g_{i}$ & 23.85 & 61.28 & 14.87 \\
\hline 世 & & & 聶 & 27.01 & 62.80 & 10.19 \\
\hline 侮 & 州 & 毁 & 田 & 35.50 & 58.00 & 6.50 \\
\hline 価 & 州 & 安 & 9 & 39.32 & 57.09 & 3.59 \\
\hline 大 & & & 和 & 41.71 & 52.28 & 6.01 \\
\hline 巨 & & & 样 & 25.25 & 59.68 & 15.07 \\
\hline$千$ & 集 & 中 & 部 & 19.63 & 59.45 & 20.92 \\
\hline 北 & $B$ & 俈 & 州 & 26.94 & 61.96 & 1.1 .30 \\
\hline 村 & 山 & 盆 & 地 & 9.44 & 48.64 & 41.92 \\
\hline 绩 & & & 中 & 22.78 & 57.19 & 20.03 \\
\hline
\end{tabular}

本地方の艺れは平均值 $41.19 \pm 0.06$ を示し， Iwanowsky の分類でみれば第 4 表の如く短腕 に属するものが過半数であり，他地方と比し て短腕のものが多いことがわかる。

\section{III 頭部に関する研突成績}

頭部に関する種々の計測値及び 指数值は人 種相互間の親近度を比較するらえに最も必要 且つ重要な意義を有するものである，頭部に 関すつる主要計測值及び 指数值を一括して第 5 . 表に示した。そのうち頭最大長, 頭最大幅, 頭長幅指数, 耳頭高, 頭長耳頭高指数, 頭幅. 耳頭高指数を特に取り出し検討を加えた。

第 5 表 頭部の計測值及び指数值

\begin{tabular}{|c|c|c|c|}
\hline 形 & & & 才野从括域地方人 \\
\hline $\mathrm{N}$ & & & 528 \\
\hline $\begin{array}{c}\text { 㑔 投 大 } \\
\text { (m) }\end{array}$ & $\begin{array}{l}M \pm m \\
0 \pm m \\
v \pm m\end{array}$ & & $\begin{array}{r}188.83 \pm 0.30 \\
6.97 \pm 0.20 \\
3.65 \pm 0.11\end{array}$ \\
\hline $\begin{array}{c}\text { 可 大 幅 } \\
(\mathrm{mm})\end{array}$ & $\begin{array}{l}M \pm \\
0 \pm m \\
v \pm m\end{array}$ & & $\begin{array}{r}153.62 \pm 0.25 \\
5.91 \pm 0.01 \\
3.85 \pm 0.11\end{array}$ \\
\hline 㑔長蝠指数 & $\begin{array}{l} \pm m \\
0 \pm m \\
v \pm m \\
\end{array}$ & & $\begin{array}{r}81.84 \pm 0.22 \\
4.2 \\
5.1 \pm 0.13 \\
5.18 \pm 0.15\end{array}$ \\
\hline $\begin{array}{cc}\text { 耳 } & \text { 湎 高 } \\
(\mathrm{mm}) & \end{array}$ & $\begin{array}{l}M \pm m \\
\sigma \pm m \\
v \pm m\end{array}$ & & $\begin{array}{r}127.67 \pm 0.39 \\
8.96 \pm 0.26 \\
7.01 \pm 0.20\end{array}$ \\
\hline 可球目顽高背数 & $\begin{array}{l}M \pm m \\
0 \pm m \\
v \pm \mathrm{m}\end{array}$ & $\begin{array}{l}0 \\
\mathrm{v}\end{array}$ & $\begin{array}{r}68.22 \pm 0.22 \\
5.17 \pm 0.16 \\
7.59 \pm 0.24 \\
\end{array}$ \\
\hline 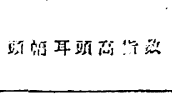 & $\begin{array}{l}\mathrm{i} \pm \mathrm{m} \\
0 \pm \mathrm{m} \\
\mathrm{v} \pm \mathrm{m}\end{array}$ & $\begin{array}{l}o \\
\mathrm{v}\end{array}$ & $\begin{array}{l}3.33 \pm 0.25 \\
5.77 \pm 0.17 \\
6.93 \pm 0.20 \\
\end{array}$ \\
\hline 板小前顽 的 & $\begin{array}{l}H \pm m \\
\sigma \pm m \\
V \pm m\end{array}$ & $\begin{array}{l}\sigma \\
\mathrm{V}\end{array}$ & $\begin{array}{r}110.40=0.23 \\
5.30 \pm 0.16 \\
2.31 \pm 0.07\end{array}$ \\
\hline 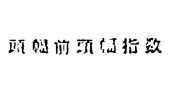 & $\begin{array}{l}u \pm m \\
\sigma \pm m \\
v \pm m\end{array}$ & $\begin{array}{l}0 \\
v\end{array}$ & $\begin{array}{r}72.24 \pm 0.16 \\
3.76 \pm 0.11 \\
5.21 \pm 0.16\end{array}$ \\
\hline
\end{tabular}

（1）頭最大長及び頭最大幅

頭最大長及び頭最大幅は頭型及び 種々の頭 部指数を算出するに基本となる 重要な計測值 でおり, Anders, Retzius 以来，重要な人種 型質として現在に至るまで多数の研究者によ つて使用されている。

元来，頭型を数字で表現することは困難な ことである。従つてこれらの頭部の諸計測値 
或は指数值で以て 直ちに頭型を推定すること に種々の難点を有している。しかし，頭最大 長及び頭最大幅は身体軀幹部の諸測定値に比 較して後天的な影響を受けること極めて少 なく，且つ骨部のために測定誤差が少ないと いら利点があるので，兄れらを啟密に測定し て，種々の計測值及び乞れらより求められた 指数を算出し，元れらに基ずいて頭型を比較 するならば，かなり正確に民族的特徵が窥わ れる・しかも, 現在のところ不完全ではある

第 6 表 頭最大長に於ける熊野川流域 地方人と他地方人との型差

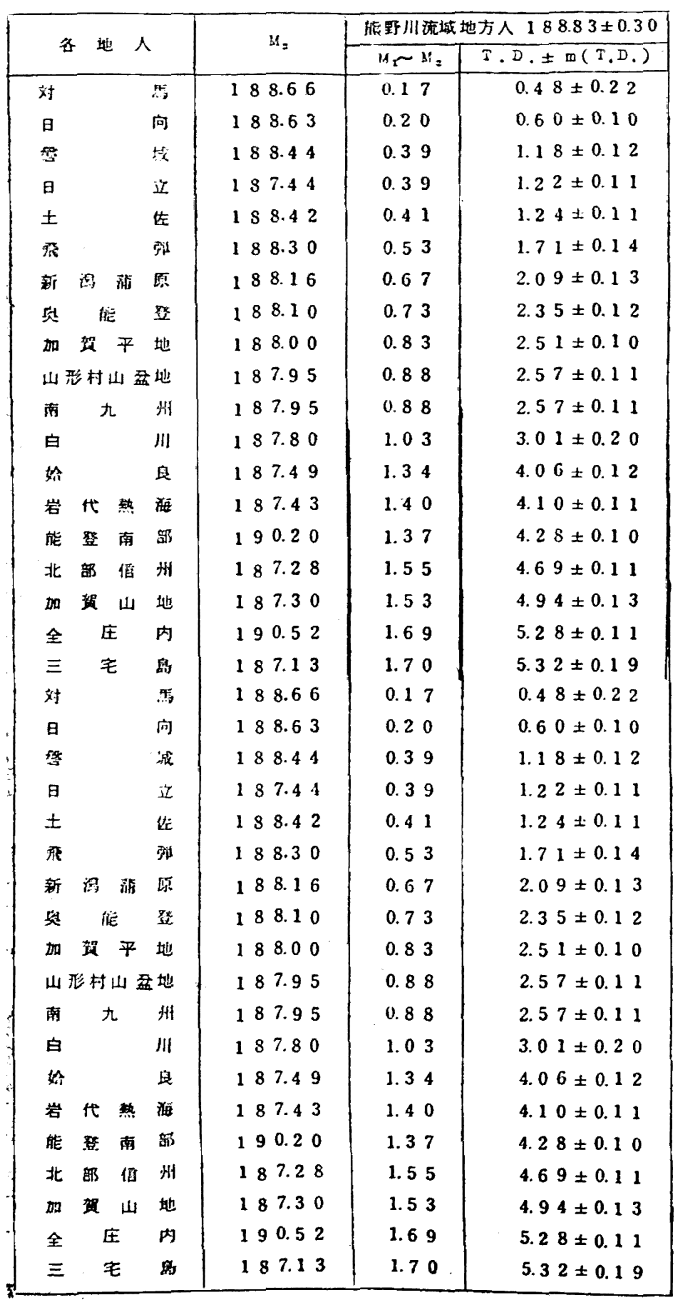

がここ礼以上の方法はないようである。

本地方人の頭最大長は $188.83 \pm 0.30 \mathrm{~mm}$ で あり， その他地方人との型差を久れば第 6 表 の如くで対馬，日向，磐城，日立，土佐の諸 地方とは型差 2 以下で親近度が大であり，信 州飯田, 越中 (磚波), 出雲, 相模平野とは親 近度が小で山ることを示している。

頭最大幅は公の平均值 $153.62 \pm 0.25 \mathrm{~mm}$ で 他地方どの型差は第 7 表の如くで，南九州， 北部信州，岩手下閐伊，巨摩の諸地方とは親 近度が大であり, 相模平野, 北海道アイヌ,

第 7 表 頭最大幅に於ける熊野川流域 地方と他地方の型差

\begin{tabular}{|c|c|c|c|c|}
\hline \multirow{2}{*}{\multicolumn{2}{|c|}{ 各 地 $人$}} & \multirow{2}{*}{$\because$} & \multicolumn{2}{|c|}{ 借野川流域地才人 $153.62 \pm 0.25$} \\
\hline & & & $\therefore n_{1} \sim n_{1}$ & $T, D . \pm n\left(T, D_{0}\right)$ \\
\hline 九 & 州 & 153.61 & 0.02 & $0.07 \pm 0.11$ \\
\hline 北部 保 & 消 & 153.82 & 0.19 & $0.70 \pm 0.12$ \\
\hline 岩手下阴 & FP & 153.30 & 0.33 & $1.08 \pm 0.13$ \\
\hline E & 突 & I 53.20 & 0.43 & $1.62 \pm 0.14$ \\
\hline 火 & 和 & 153.11 & 0.52 & $1.77 \pm 0.10$ \\
\hline 估肚上伊； & F & 152.96 & 0.67 & $2.47 \pm 0.13$ \\
\hline 対 & Es & 154.26 & 0.63 & $2.51 \pm 0.19$ \\
\hline 信非峸 & 田 & 154.45 & 0.82 & $291 \pm 0.16$ \\
\hline 仙州室 & 2 & 152.73 & 0.20 & $\therefore 59 \pm 0.15$ \\
\hline 千菉中 & is & 154.74 & 1.11 & $3.87 \pm 0.11$ \\
\hline$E$ & $\omega_{j}$ & 152.54 & 1.09 & $4.24 \pm 0.18$ \\
\hline 因 & 蚂 & $155.0 \mathrm{~s}$ & 1. i 5 & $4.91 \pm 0.12$ \\
\hline 㾏 & ['s & 155.01 & 1.38 & $4.95 \pm 0.11$ \\
\hline 㭛 & 票 & 152.30 & 1.33 & $5.04 \pm 0.11$ \\
\hline 山 & 2 & 152.08 & 1. 55 & $5.68 \pm 0.12$ \\
\hline tis 王 䔩 & 的 & 152.16 & 1.47 & $5.71 \pm 0.12$ \\
\hline 汭 & 4 & 151.92 & 1.71 & $5.79 \pm 0.13$ \\
\hline 姶 & Q & 155.47 & 1.84 & $6.29 \pm 0.12$ \\
\hline 能 & 登 & 151.90 & 1.73 & 6. $38 \pm 0.10$ \\
\hline 甲 & 装 & 151.64 & 1.99 & $7.54 \pm 0.10$ \\
\hline t & 仵 & 151.46 & 2.17 & $7.79 \pm 0.12$ \\
\hline 岩 代 䓡 & 旃 & 150.95 & 2.68 & $8.54 \pm 0.11$ \\
\hline 山形村山强， & & 151.20 & 2.43 & $8.72: 0.11$ \\
\hline 落 & 度 & 150.96 & 2.67 & $9.31 \pm 0.21$ \\
\hline 越中（䀘波） & ) & 150.92 & 2.71 & $9.72 \pm 0.16$ \\
\hline 日 & 向 & 150.8 .3 & 2.80 & $10.33 \pm 0.10$ \\
\hline 加 㔔 山 & 地 & 150.80 & 2.83 & $10.72 \pm 0.13$ \\
\hline 化埾 菏 & th & 150.70 & 2.93 & $10.81 \pm 0.10$ \\
\hline 白 & III & 150.70 & 2.93 & $10.81 \pm 0.20$ \\
\hline 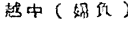 & ) & 150.70 & 2.93 & $11.39 \pm 0.13$ \\
\hline 新骂 湖 & 原 & 150.07 & 3.56 & $12.06 \pm 0.13$ \\
\hline 日 & 立 & 150.01 & 3.62 & $13.35 \pm 0.12$ \\
\hline 束 & 海 & 149.96 & 3.67 & $13.54 \pm 0.12$ \\
\hline 相 紋 平 & EF & 148.99 & 4.64 & $15.72 \pm 0.13$ \\
\hline 北游逆 フィ & x & 149.30 & 4. 33 & $16.41 \pm 0.16$ \\
\hline 加 驽 平 & 地 & 149.10 & 4.53 & $16.71 \pm 0.10$ \\
\hline 登 & 域 & 148.90 & 4.73 & $17.45 \pm 0.12$ \\
\hline
\end{tabular}


加贺山地, 磐城の諸地方とは親近度が薄いこ とを示している。

(2) 頭長幅指数

頭長幅指数は頭最大幅の 頭最大長に 対する 比である。本指数は頭型を簡単に現わすこと が出来るので人種の 親近度を示す重要な指標 となつている。

調査地区住民の气の平均値は $81.84 \pm 0.22$ で ある. それを Martin の頭型分類でみると， 第 8 表の如くで, 中頭型の $37 \%$ が最も多く, 次で短頭型の $35 \%$ となつて特り，短頭型と過 短頭型を合わせると $55 \%$ となり，稍短頭の傾 向にある。また，本指数を他地方との型差で みると第 9 表の如く, 対馬, 南九州, 三宅島 等と親近度が深く, 磐城, 加賀山地, 北海道 アイヌ，相模平野などの 諸地方と親近度が小 であることを示している。

第 8 表 頭長幅指数頭型分類表

\begin{tabular}{|c|c|c|c|c|c|}
\hline 政 & & 坛顼 型 & 中影 型 & 短，咟 型 & 迥短首望 \\
\hline 职是筁指数 & & $\sim 75.9$ & $\stackrel{76.0}{\sim} 80.9$ & $\begin{array}{r}81.0 \sim \\
85.4\end{array}$ & $85.5 \sim$ \\
\hline 的 纾 & & 6.83 & 37.38 & 35.29 & 20.49 \\
\hline 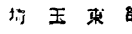 & 鄚 & 4.72 & 33.64 & 42.03 & 19.61 \\
\hline 粮 & 城 & 18.75 & 54.74 & 22.73 & 3.79 \\
\hline 便形安 & 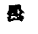 & 0.57 & 43.67 & 48.20 & 7.56 \\
\hline 太 & 和 & 5.25 & 31.63 & 38.82 & 24.30 \\
\hline 加贺山 & 地 & 4. 78 & 53.09 & 34.83 & 7.30 \\
\hline 传 州 领 & 田 & 1.50 & 20.00 & 45.00 & 33.50 \\
\hline 伍州上栗品 & 部 & 2.00 & 31.00 & 48.00 & 19.00 \\
\hline 此 & $n$ & 1. 60 & 42.40 & 49.60 & 6.40 \\
\hline 山 & 空 & 2.14 & 31.64 & 45.84 & 20.38 \\
\hline$\lambda$ & 鼻 & 1.79 & 30.00 & 46.67 & 21.54 \\
\hline 加 视 平 & 地 & 14.81 & 54.88 & 27.34 & 2.97 \\
\hline 央 舵 & 㷅 & 5.47 & 49.27 & 39.96 & 5.29 \\
\hline 俚 登 雨 & 部 & 14.76 & 55.83 & 26.49 & 2.12 \\
\hline 蚂 & 中 & 27.65 & 54.25 & 16.48 & 1.59 \\
\hline 柨 & 彄 & 5.35 & 48.07 & 39.85 & 6.72 \\
\hline it & 中 & 6.79 & 32.15 & 36.99 & 24.07 \\
\hline 山形村江盆动 & & 9.12 & 49.12 & 31.20 & 10.56 \\
\hline 比 & A: & 3.10 & 45.35 & 40.78 & 10.77 \\
\hline 41 梨巨 & $188^{\circ}$ & 3.49 & 29.25 & 46.64 & 20.17 \\
\hline 下 藻 斤 & 战 & 3.45 & 24.96 & 42.20 & 28.99 \\
\hline 伊 & 形 & 1.69 & 20.97 & 17.00 & 24.34 \\
\hline 5 留 北 & 部 & 3.66 & 34.38 & 41.19 & 20.77 \\
\hline
\end{tabular}

\section{（3）耳頭高}

耳頭高は間接法で身長から耳珠高を引いて 求めた。穴の平均值は $127.67 \pm 0.39 \mathrm{~mm}$ であ
第 9 表 頭長幅指数に於ける熊野川流域 地方と他地方の型差

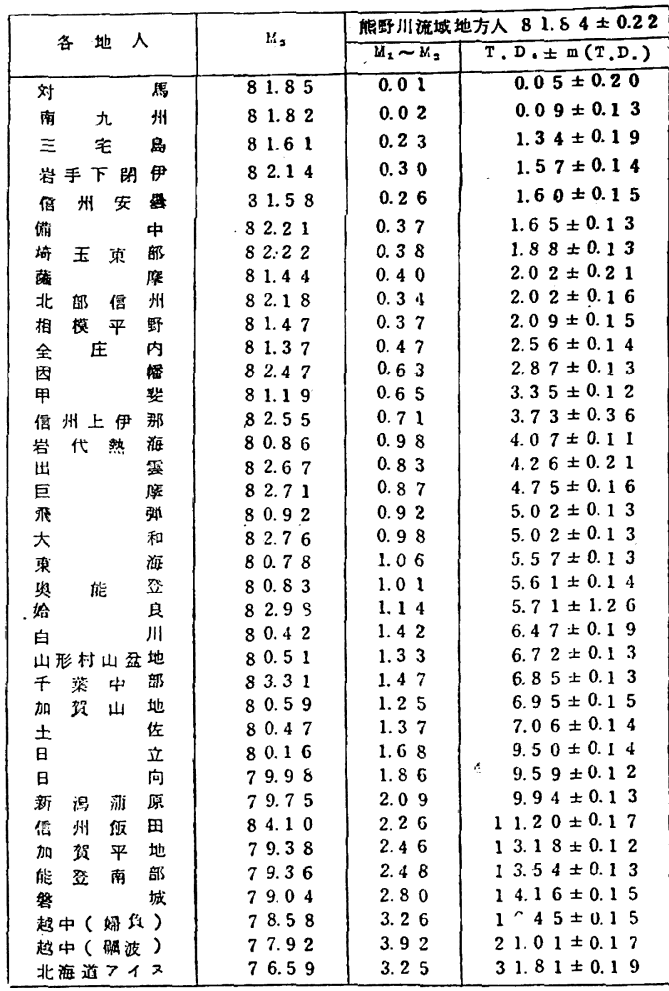

る。これを他地方人との型差でみれば，第 10 表の如くで, 信州飯田, 巨摩, 東海, 日向の 諸地方と親近度が大であり，白川，奥能登， 全庄内とは親近度が小である。

(4) 頭長耳頭高指数

本指数は頭最大長に対する 耳頭高の比を示 すものであつて，本地方人のその平均值は 68.22士0.22 を示した。 それを Saller の分類 でみると第 11 表の如く，高頭型が 85\% の多 くを占め, 低頭型に属するものはわずかに 2.5 \%にすぎない，他地方人との型差をみれば， 第 12 表の如くで信州上伊郡, 信州安曇, 相模 平野, 東海の諸地方と近縁関係が窥われるが, 白川, 越中, 全庄内, 因幡, 北海道アイヌの 諸地方とは親近度が小であることが分る。

（5）頭幅耳頭高指数

本指数は耳頭高の頭最大幅に対する 比率で 
第 10 表 耳頭高に於ける能野川流域地方と他 地方の型差

\begin{tabular}{|c|c|c|c|c|}
\hline \multirow{2}{*}{\multicolumn{2}{|c|}{ 各地人 }} & \multirow{2}{*}{$\mathbf{x}}$, & \multicolumn{2}{|c|}{ 稫里川流枝地方人 $127.67 \pm 0.37$} \\
\hline & & & $\mathrm{u}_{2} \sim \mathrm{u}_{2}$ & $T, D . \pm m\left(T . D_{.}\right)$ \\
\hline 昍州 鲀 & 田 & 127.68 & 0.01 & $0.02 \pm 0.15$ \\
\hline & 策 & 127.60 & 0.07 & $0.15 \pm 0.15$ \\
\hline 東 & 浑 & 127.57 & 0.10 & $0.21 \pm 0.11$ \\
\hline 日 & 向 & 127.42 & 0.25 & $0.65 \pm 0.1 .1$ \\
\hline 薜 & 7 & 127.34 & 0.33 & $0.86 \pm 0.19$ \\
\hline 日 & 立 & 127.32 & 0.35 & $0.98 \pm 0.12$ \\
\hline$千 \bar{x}$ 中 & 部 & 128.16 & 0.49 & $1.18 \pm 0.12$ \\
\hline 保出案 & a & 126.98 & 0.69 & $1.53 \pm 0.12$ \\
\hline \pm & 佐 & 127.67 & 1.02 & $2.36 \pm 0.12$ \\
\hline 出 & 西虹 & 126.71 & 0.96 . & $2.38 \pm 0.10$ \\
\hline 估州上色 & 那 & 126.37 & 1.30 & $3.40 \pm 0.14$ \\
\hline 甲 & 恝 & .126 .27 & 1.40 & $3.94 \pm 0.11$ \\
\hline 坸 玉 䅇 & 被 & 126.08 & 1.59 & 4. $00 \pm 0.12$ \\
\hline 三 㫣 & 我 & 125.68 & 1.99 & $4.41 \pm 0.19$ \\
\hline 岩手下成 & 伊 & 125.48 & 2.19 & $4.42 \pm 0.12$ \\
\hline 対 & 慙 & 125.61 & 2.06 & 4. $57 \pm 0.21$ \\
\hline 梁 & 卌 & 125.60 & 2.07 & $5.00 \pm 0.11$ \\
\hline 加 费 平 & 地 & 125.80 & 1.87 & $5.08 \pm 0.11$ \\
\hline 北济 >1 & x & 125.70 & 1.97 & $5.16 \pm 0.17$ \\
\hline 始 & 良 & 125.32 & 2.35 & $5.17 \pm 1.25$ \\
\hline 封中（蛇负 & ) & 125.30 & 2.37 & $6.20 \pm 0.13$ \\
\hline 岩 代 䓡 & 复 & 125.02 & 2.67 & $7.20 \pm 0.12$ \\
\hline 大 & 和 & 130.91 & 3.24 & $7.35 \pm 0.10$ \\
\hline 相 知 & 时 & 124.36 & 3. 31 & $7.67 \pm 0.13$ \\
\hline 新 9 蔽 & 原 & 130.98 & 3.31 & $8.01 \div 0.13$ \\
\hline 北 卙 佰 & 州 & 124.22 & 3.45 & $8.34 \pm 0.12$ \\
\hline 加山、 & 地 & 124.50 & 3.17 & $8.62 \pm 0.13$ \\
\hline 楜 & 中 & 124.04 & 3.63 & $8.73 \pm 0.10$ \\
\hline$t$ & $B H$ & 123.94 & 3. 73 & $9.02 \pm 0.11$ \\
\hline 山形村山盈 & 地 & 123.68 & 3.99 & $9.65 \pm 0.12$ \\
\hline 然 & 城 & 122.52 & 5.15 & $9.88 \pm 0.12$ \\
\hline 起中（磁诰 & ) & 123.41 & 4. 26 & $11.16 \pm 0.16$ \\
\hline 因 & 谭 & 122.06 & 5.16 & $12.42 \pm 0.12$ \\
\hline 蛙、登 南 & 部 & 123.20 & 4.47 & $13.05 \pm 0.12$ \\
\hline 全 座 & 内 & 121.79 & $5.8 \mathrm{~s}$ & $14.22 \pm 0.12$ \\
\hline 证 & 歮 & 120.60 & 7.07 & $19.95 \pm 0.12$ \\
\hline 白 & 川 & 117.80 & 9.87 & $24.87 \pm 0.20$ \\
\hline
\end{tabular}

あつて，本地方人の平均値は $83.33 \pm 0.25 て ゙$ ある、それを Martin-Saller の頭幅耳頭高指 数による 頭型分類によれば，第 13 表の如く Metrio Kephar が最も多く $44 \%$ を占め，次い で Apro Kephar の36\%, Tapeino Kephar の 20\% とい5順になつている。をた，他地方 人との型差でみると第 14 表の如く，人（種親 近度は甲斐, 越中 (婦負), 巨摩, 相模平野な ぞと大であり, 白川, 全庄内, 因幡, 奥能登 などの諸地方と小であることを示している.
第 11 表 頭長耳頭高指数分類表

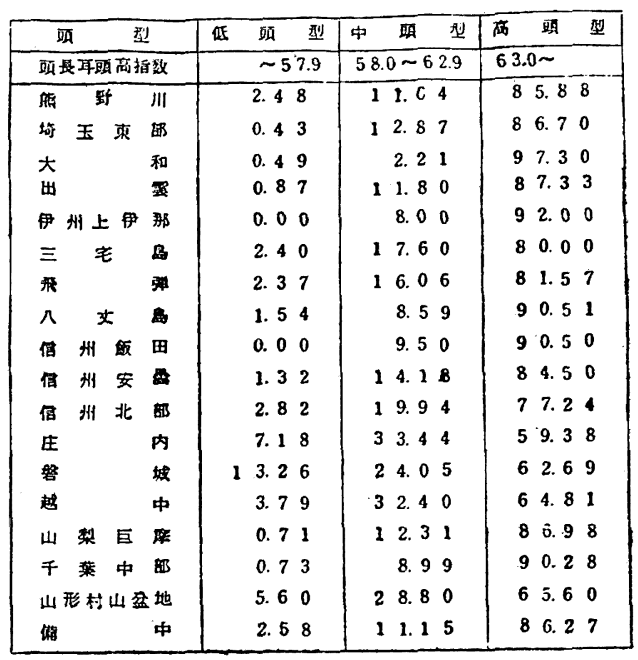

第 12 表 頭長耳頭高指数に於ける熊野川 流域地方と他地方との型差

\begin{tabular}{|c|c|c|c|c|}
\hline \multirow{2}{*}{\multicolumn{2}{|c|}{ 各 地 $ᄉ$}} & \multirow{2}{*}{$M_{2}$} & \multicolumn{2}{|c|}{ 成野川流城地方人 $68.22 \neq 0.22$} \\
\hline & & & $N_{1} \sim k_{i}=$ & T.D.tm(T.D.) \\
\hline 佋州上伊判 & & 68.09 & 0.13 & $0.60 \pm 0.11$ \\
\hline 面州炎目 & & 68.06 & 0.16 & $0.61 \pm 0.11$ \\
\hline 相 筫 平 野 & 政 & 67.98 & 0.24 & $0.96 \pm 0.13$ \\
\hline 埼 玉 東 的 & 蚛 & 67.97 & 0.25 & $1.08 \pm 0.12$ \\
\hline 束 & 堽 & 68.67 & 0.45 & $1.76 \pm 0.11$ \\
\hline 日 & 向 & 67.78 & 0.44 & $2.03 \pm 0.11$ \\
\hline 甲 & 业 & 67.75 & 0.47 & $2.22 \pm 0.15$ \\
\hline 日 & 立 & 67.82 & 0.40 & $2.29 \pm 0.14$ \\
\hline 䘝 & 8 & 68.79 & 0.57 & $2.52 \pm 0.20$ \\
\hline$千$ 莱 中 & 觔 & 68.89 & 0.67 & $2.76 \pm 0.12$ \\
\hline 巨 & 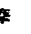 & 69.11 & 0.89 & $3.49 \pm 0.15$ \\
\hline 熘 & 中 & 67.31 & 0.91 & $3.66 \pm 0.11$. \\
\hline 出 & 显 & 69.20 & 0.98 & $4.26 \pm 0.17$ \\
\hline \pm & 㝾 & 67.12 & 1.10 & $4.43 \pm 0.12$ \\
\hline 新谓莎 & 戠 & 69.40 & 1.18 & $4.51 \pm 0.12$ \\
\hline 诺手下閉伊 & 7 & 67.30 & 0.92 & 4. $53 \pm 0.13$ \\
\hline 姶良 & 量 & 66.96 & 1.26 & $4.88 \pm 1.27$ \\
\hline 宅 & S & 66.89 & 1.33 & $5.35 \pm 0.14$ \\
\hline 侻 州 级 & 田 & 69.53 & 1.31 & $5.67 \pm 0.42$ \\
\hline 岩 代 然 & 每 & 67.04 & 1.18 & $5.69 \pm 0.12$ \\
\hline 加贺平 & 也 & 67.02 & 1.20 & $5.79 \pm 0.11$ \\
\hline 棸 & 7 & 66.76 & 1.46 & $6.17 \pm 0.11$ \\
\hline 对 & 馬 & 66.49 & 1.73 & $6.79 \pm 0.20$ \\
\hline 加繁山 & 也 & 66.56 & 1.66 & $7.68 \pm 0.13$ \\
\hline 北部 位 & H & 66.30 & 1.92 & $8.12 \pm 0.12$ \\
\hline 湳 九 & H & 65.96 & 2.28 & $9.64 \pm 0.11$ \\
\hline 大 & 和 & 71.06 & 2.84 & $9.70 \pm 0.99$ \\
\hline 砦 & 贱 & 64.82 & 3.40 & $12.00 \pm 0.17$ \\
\hline 能 登 南 影 & 觓 & 65.44 & 2.78 & $15.09 \pm 0.12$ \\
\hline 山形村山备地 & & 64.60 & 3.62 & $15.31 \pm 0.11$ \\
\hline 奥 供 驾 & 㱠 & 64.64 & 3.58 & $18.00 \pm 0.13$ \\
\hline 北海道 フイス & 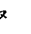 & 64.18 & 4. 04 & $18.30 \pm 0.17$ \\
\hline 因 & 楼 & 64.55 & 3.67 & $18.46 \pm 0.15$ \\
\hline 全 庄 内 & 内 & 63.94 & 4. 28 & $18.53 \pm 0.11$ \\
\hline 越中（础波） & & 64.29 & 3. 93 & $18.58 \pm 0.16$ \\
\hline 超中（妇鱼） & & 63.35 & 4. 87 & $22.54 \pm 0.13$ \\
\hline 白 川 & m & 62.75 & 5.47 & $2313 \pm 020$ \\
\hline
\end{tabular}


第 13 表 頭幅耳頭高指数頭型分類表

\begin{tabular}{|c|c|c|c|c|}
\hline 副 & & $\begin{array}{l}\text { Tapeino } \\
\text { Kephar }\end{array}$ & $\begin{array}{l}\text { Motrio } \\
\text { Kephar }\end{array}$ & ${ }^{\text {A pro }}{ }_{\text {Kophar }}$ \\
\hline 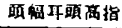 & & $\sim 78.9$ & $79.0 \sim 84.9$ & $85.0 \sim$ \\
\hline 筷 & 111 & 20.11 & 44.06 & 35.82 \\
\hline 畦玉西 & 酧 & 19.62 & 45.65 & 34.73 \\
\hline 繁 & 城 & $\begin{array}{lll}3 & 3.71\end{array}$ & $\begin{array}{lll}3 & 4.0 & 9\end{array}$ & $\begin{array}{l}32.20 \\
0\end{array}$ \\
\hline 俉 州安 & 8 & 27.60 & 37.43 & 34.97 \\
\hline 大 & 和 & 13. 74 & 40.47 & 45.79 \\
\hline 趣 & 中 & 23. 34 & 47.48 & 30.16 \\
\hline 事 & 糔 & 24.91 & $\begin{array}{lll}42.22 \\
\end{array}$ & $\begin{array}{l}32.88 \\
\end{array}$ \\
\hline 俉州上伊 & 那 & 18.00 & 53.00 & 29.00 \\
\hline 俉州㢳 & 田 & $\begin{array}{lll}2 & 3: 0 & 0\end{array}$ & 44.00 & 33.00 \\
\hline 宅 & 呙 & 30.40 & 39.20 & 30.40 \\
\hline 头 & 禹 & 24.10 & 42.82 & $\begin{array}{l}33.08 \\
\end{array}$ \\
\hline 出 & 零 & 17.29 & 44.71 & $\begin{array}{lll}38.0 & 0\end{array}$ \\
\hline 纱 & 中 & 26.33 & 44.43 & 29. 24 \\
\hline 山形村山盆 & 地 & 40.48 & 44.48 & 15.04 \\
\hline 千莱 & 㺃 & 24.04 & 43.12 & $\begin{array}{l}32.84 \\
4\end{array}$ \\
\hline 告 & 内 & 5 4.81 & $\begin{array}{l}33.93 \\
\end{array}$ & 11.26 \\
\hline 岩 代＼cjkstart䇾 & 海 & 7. 13 & 55.60 & 27.27 \\
\hline 栵 & 榉 & 14.63 & $\begin{array}{l}49.01 \\
\end{array}$ & 36.36 \\
\hline 止 & 那 & 19.85 & 49.63 & $\begin{array}{ll}30.52 \\
\end{array}$ \\
\hline 州 北 & 蚂 & 29. 90 & 44.35 & 25.75 \\
\hline
\end{tabular}

第 15 表 顔面の計测值及び指数值

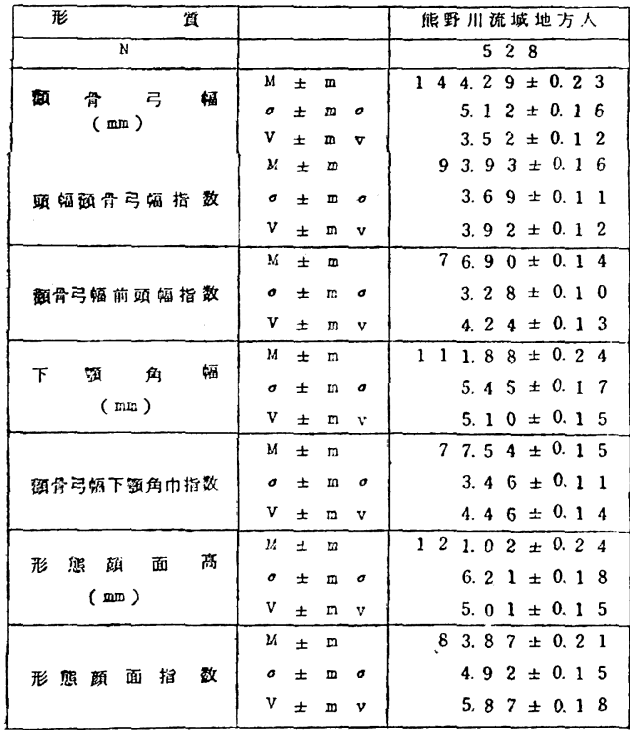

\section{IV 顔面に関する研究成績}

顔面に括ける諸測定は軀幹四肢及び頭部に 招ける測定結果と同様, 人種学的検討に重要 な指標となつている。その分析法は所調「顔 つき」を数字で現わすものである、それらの 計測値及び 指数值を一括して第 15 表に示し
第 14 表 頭幅耳頭高指数に於ける熊野川 流域地方々他地方の型差

\begin{tabular}{|c|c|c|c|c|}
\hline \multirow{2}{*}{\multicolumn{2}{|c|}{ 各 地 人 }} & \multirow{2}{*}{$M_{2}$} & \multicolumn{2}{|c|}{ 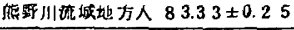 } \\
\hline & & & $\mathrm{y}_{1} \sim \mathrm{M}_{2}$ & $T, D . \pm m(T, D)$, \\
\hline 甲 & 桨 & 83.31 & 0.02 & $0.08 \pm 0.10$ \\
\hline 越中（婿角） & & 83.26 & 0.07 & $0.27 \pm 0.13$ \\
\hline 巨 & 盟 & 83.43 & 0.10 & $0.34 \pm 0.15$ \\
\hline 相 平 & 影 & 83.49 & 0.17 & $0.60 . \pm 0.13$ \\
\hline 出 & 蟲 & 83.55 & 0.22 & $0.82 \pm 0.13$ \\
\hline 伯州欧 & 田 & 33.01 & 0.32 & $1.19 \pm 1.63$ \\
\hline \pm & 佐 & 83.76 & 0.43 & $1.47 \pm 0.06$ \\
\hline 坋 王 莱 & 部 & $82.8:$ & 0.49 & $1.87 \pm 0.12$ \\
\hline 千 䎹 中 & 部 & 82.77 & 0.56 & $2.06 \pm 0.12$ \\
\hline 北海道フィン & 又 & 83.93 & 0.60 & $2.23 \pm 0.18$ \\
\hline 信州上伊聿 & 那 & 82.62 & 0.71 & $2.79 \pm 0.13$ \\
\hline 积 & 架 & 82.56 & 0.77 & $2.79 \pm 0.11$ \\
\hline 加 贺 山 & 地 & 82.56 & 0.77 & $3.02 \pm 0.13$ \\
\hline 若 代 熟 & 海 & 82.54 & 0.79 & $3.10 \pm 0.12$ \\
\hline 越中（洒波） & & 82.44 & 0.89 & $3.40 \pm 0.16$ \\
\hline 沿州安 & a & 84.49 & 1.16 & $3.74 \pm 0.12$ \\
\hline 批 埾 南 & LB & 82.46 & 0.87 & $3.76 \pm 0.11$ \\
\hline 瓷 & R & 84.46 & 1.13 & $4.32 \pm 0.20$ \\
\hline 智 & 找 & 81.84 & 1. 49 & $4.51 \pm 0.12$ \\
\hline 三年 & 量 & 82.00 & 1.33 & $4.69 \pm 0.20$ \\
\hline 加 投 平 & 地 & 84.48 & 1.15 & $4.74 \pm 0.10$ \\
\hline 日占 & 向 & 84.64 & 1. 34 & $5.13 \neq 0.10$ \\
\hline 岩手下的伊 & 君 & 81.54 & 1.79 & $5.42 \pm 0.16$ \\
\hline 大 & 和 & 85.05 & 1.72 & $5.79 \pm 0.10$ \\
\hline 埇 & 中 & 81.55 & 1. 78 & $6.28 \div 0.11$ \\
\hline 束 & 海 & 85.23 & 1.90 & $6.32 \pm 0.12$ \\
\hline 対 & 馬 & 81.42 & 1.91 & $6.55 \pm 0.21$ \\
\hline 日 & 立 & 84.90 & 1.57 & $6.95 \pm 0.13$ \\
\hline 新 泊 蒲 & E⿵ & 85.80 & 2.47 & $8.47 \pm 0.13$ \\
\hline 㣮 九 & 州. & 80.79 & 2.54 & $9.47 \pm 0.11$ \\
\hline 北 郎 僄 州 & 州 & 80.72 & 2.63 & $9.47 \pm 0.11$ \\
\hline 始 & 良 & 80.45 & 2.88 & $9.76 \pm 1.27$ \\
\hline 山形村山盗地 & & 80.22 & 3. 11 & $11.60 \pm 0.11$ \\
\hline 能 & 辇 & 80.04 & 3.29 & $13.25 \pm 0.12$ \\
\hline 因 & 婹 & 78.32 & 5.01 & $16.68 \pm 0.11$ \\
\hline 庄 & 内 & 78.65 & 4. 68 & $16.98 \pm 0.11$ \\
\hline .白 & III & 78.27 & 5.06 & $18.36 \pm 0.20$ \\
\hline
\end{tabular}

た。

\section{（1）顴骨弓幅}

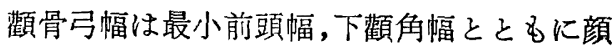

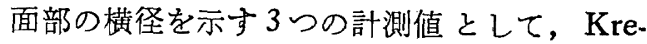
tchmer, Sigaud, Kruse 等の体型分類に付属 する顔型分類として，現在に至るまで重要な 役割を果している．更に顴骨弓幅は環境など 外的因子による影響を受けることが 比較的少 なく，且つ変異係数も小であるので，遺伝関 係を窥知するに適当で㟧るるされている。

本地方人のその平均值は, 144.29士0.23で, 
変異係数は 3.52 である。

\section{（2）頭幅顴骨弓幅指数}

本指数は顴骨弓幅の 頭最大幅に 対する比率 である. 本地方人のそれは平均值 $93.93 \pm 0.16$ で示さ礼た。

第 16 表 顴骨弓幅下顎角幅指数顔型 分類表 (\%)

\begin{tabular}{|c|c|c|c|c|c|c|}
\hline 地方名 & 烈 & $\begin{array}{l}\text { 型 } \\
\sim 69.9\end{array}$ & $\begin{array}{r}70.0 \sim \\
74.9 \\
\end{array}$ & $\begin{array}{r}\text { 中 } 5.0 \text { 管 } \\
79.9\end{array}$ & $\begin{array}{r}\text { 㕕 } 0.0 \text { 型 } \\
84.9\end{array}$ & $\begin{array}{l}\text { 迥㕕型 } \\
85.0 \sim\end{array}$ \\
\hline 暨 & 川 & 1.52 & 21.33 & 51.62 & 24.76 & 0.76 \\
\hline 战 & 中 & 1.45 & 19.06 & 54.94 & 21.97 & 2.58 \\
\hline 村 & 地 & 1.28 & 22.56 & 51.68 & 21.12 & 3. 36 \\
\hline & 内 & 0.33 & 10.77 & 52.86 & 33.28 & 2.77 \\
\hline 代 鰵 & 每 & 0.71 & 10.14 & 59.61 & 27.09 & 2.45 \\
\hline 州安 & 숌 & 0.38 & 5.48 & 58.60 & 34.41 & 1.13 \\
\hline 州 & 田 & 0.50 & 15.00 & 57.50 & 25.00 & 2.00 \\
\hline 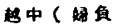 & ) & 1.07 & 18.29 & 56.45 & 23.65 & 0.53 \\
\hline 8 & 城 & 1.14 & 14.21 & 52.27 & 26.51 & $5.8 \mathrm{I}$ \\
\hline 估州上伊 & 3 & 1.00 & 20.00 & 52.00 & 26.00 & 11.00 \\
\hline 大 & 和 & 0.40 & 7.67 & 52.21 & 36.12 & 3.87 \\
\hline & 盛 & 1.00 & 20.00 & 52.80 & 24.80 & 0.80 \\
\hline $\bar{R}$ & \% & 1.49 & 26.03 & 51.18 & 20.42 & 0.87 \\
\hline$\lambda$ & 禹 & 2.57 & 27.18 & 51.02 & 18.46 & 0.97 \\
\hline & 雲 & 0.60 & 22.72 & 60.72 & 15.01 & 0.94 \\
\hline 新相東 & 原 & 0.57 & 16.47 & 52.31 & 29.68 & 0.97 \\
\hline 绍州 北 & 部 & 0.84 & 12.29 & 52.83 & 31.91 & 2. 33 \\
\hline 平 & gf & 1.00 & 19.75 & 54.75 & 21.00 & 3.50 \\
\hline 藮中 & 8 & 0.18 & 8.99 & 55.78 & 32.11 & 2.94 \\
\hline$E$ & 需 & 2.37 & 23.32 & 54.54 & 17.00 & 2.77 \\
\hline 站 & 良 & 2.59 & 24.25 & 49.99 & 21.89 & 1.50 \\
\hline 日 & Ir. & 0.33 & 18.00 & 54.00 & 25.67 & 2.00 \\
\hline
\end{tabular}

第 17 表 形態顔面指数顔型分類表 $(\%)$

\begin{tabular}{|c|c|c|c|c|c|c|}
\hline & & $\begin{array}{l}\text { 进広型 } \\
\sim 78.9\end{array}$ & 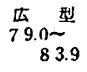 & $\begin{array}{l}\text { 中笋型 } \\
8.0 \sim \\
87.9\end{array}$ & 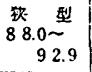 & $\begin{array}{l}\text { 唡积型 } \\
93.0 \sim\end{array}$ \\
\hline sf & & 16.57 & 35.81 & 28.95 & $14.10^{\circ}$ & $4.3 \mathrm{~s}$ \\
\hline 村山姐 & & 16.80 & 39.68 & 24.96 & 13.76 & 4.80 \\
\hline - & & 0.82 & 13.21 & 28.87 & 39.48 & 17.62 \\
\hline 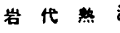 & 海 & 1.75 & 15.03 & 49.29 & 32.89 & 1.07 \\
\hline 作 州 女 & (1) & 12.85 & 40.08 & 28.17 & 15.31 & 3.59 \\
\hline 估州会 & 田 & 10.00 & 29.00 & 35.50 & 22.00 & 5.50 \\
\hline 坅 & 中 & 8.06 & 27.03 & 31.72 & 24.19 & 6.98 \\
\hline 禁 & 城 & 4.36 & 23.48 & 28.60 & 30.87 & 12.69 \\
\hline 酔州上伊 & 素 & 8.10 & 33.80 & 29.60 & 24.10 & 4.50 \\
\hline 大 & 和 & 9.60 & 32.73 & 29.21 & 21.96 & 6.49 \\
\hline$\equiv$ & 岛 & 6.40 & 26.40 & 30.40 & 30.40 & 6.40 \\
\hline 和 & ; & 17.81 & 35.24 & 29.64 & 14.82 & 2.49 \\
\hline$\Lambda$ & 象 & 1.28 & 22.56 & 36.67 & 29.23 & 10.23 \\
\hline 斗 & 零 & 4.36 & 26.01 & 33.58 & 28.21 & 7.84 \\
\hline 新皅果清 & 原 & 9.00 & 21.11 & 27.69 & 31.37 & 10.82 \\
\hline 相 平 & F & 1.00 & 9.75 & 26.75 & 39.00 & 23.50 \\
\hline 菜 中 & 部 & 6.24 & 28.44 & 33.21 & 23.85 & 8.26 \\
\hline E & 畨 & 3.56 & 23.72 & 35.57 & 28.45 & 8.69 \\
\hline 太 & 渪 & - & 0.88 & 6.46 & 22.61 & 70.05 \\
\hline 日 & 立 & 1.00 & 14.17 & 48.17 & 36.49 & 0.17 \\
\hline 料 & 中 & 8.92 & 23.59 & 29.24 & 31.34 & 7.11 \\
\hline
\end{tabular}

\section{（3）下顴角幅}

下顴角幅は前記の如く，顴骨弓幅と共に顔 型分類のうえに重要な测定値である．本地方 人のその平均值, $111.88 \pm 0.14$ である。

\section{（4）顧骨弓幅下顧角幅指数}

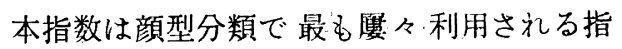
数の 1 つである. 顔面中央部以下の顔型の広 狭を示すもので, 人類学的検討のうえに重要 な指数である. 本地方人のその平均值は 77.54 土0.15でおる。それを Lundburg-Linders 及 び Saller の顔型分類でみると第 16 表の如く

第 18 表 形態顔面指数に於ける熊野川流 域地方人と他地方の型差

\begin{tabular}{|c|c|c|c|}
\hline \multirow{2}{*}{ 各 地 人 } & \multirow{2}{*}{$M_{1}$} & \multicolumn{2}{|c|}{ 能转川硫城地方人 $83.87 \pm 0.21$} \\
\hline & & $u_{1} \sim n_{3}$ & T.D. $\pm m(T, D)$. \\
\hline 侻州安 & 84.07 & 0.19 & $0.82 \pm 0.12$ \\
\hline 能 然 南 & 83.62 & 0.26 & $1.15 \pm 0.10$ \\
\hline 相 & 83.51 & 0.37 & $1.52 \div 0.11$ \\
\hline 奥 能 & 84.30 & 0.42 & $1.77 \pm 0.12$ \\
\hline 山形村山盘地 & 83.36 & 0.56 & $2.04 \pm 0.11$ \\
\hline 日 & 84.95 & 1.07 & $4.74=0.10$ \\
\hline 大 & 85.26 & 1.38 & $5.57 \pm 0.65$ \\
\hline 固 州 段 & 85.24 & 1. 36 & $5.61 \pm 0.16$ \\
\hline 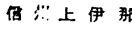 & 85.22 & 1.34 & $5.66 \pm 0.13$ \\
\hline 埇 向 來 & 84.88 & 1.00. & $5.93 \pm 0.14$ \\
\hline 北海道フイス & 85.32 & 1.44 & $5.94 \pm 0.18$ \\
\hline 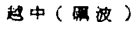 & 85.55 & 1.67 & $6.89 \pm 0.16$ \\
\hline 销 & 85.72 & 1.84 & $7.41 \pm 0.11$ \\
\hline$千$ 藮 中 & 86.04 & 2.16 & $8.92 \pm 0.12$ \\
\hline$\equiv \quad$ 宅 & 86.28 & 2.40 & $10.63 \pm 0.19$ \\
\hline 出 & 86.42 & 2.54 & $10.79 \pm 0.17$ \\
\hline \pm & 86.43 & 2.55 & $11.04 \pm 0.13$ \\
\hline$巨$ & 86.93 & 3. 05 & $12.90 \pm 0.15$ \\
\hline 超中(阵位) & 86.91 & 3.03 & $13.11 \pm 0.1: 3$ \\
\hline 然 & 87.31 & 3.43 & $13.47 \pm 0.12$ \\
\hline 承 & 87.79 & 3. 91 & 14.19 .0 .11 \\
\hline 北解 隹 & 87.44 & 3.56 & $14.70 \pm 0.11$ \\
\hline 嵌 代 椥 & 86.72 & 2.84 & $14.85 \pm 0.13$ \\
\hline 対 & 87.62 & 3.74 & $15.07 \pm 0.21$ \\
\hline 加 贺 山 & 87.44 & 3.56 & $15.77 \pm 0.13$ \\
\hline 加 级 平 & 87.70 & 3.82 & $16.15 \pm 0.10$ \\
\hline 白 & 80.03 & 3.85 & $16.28 \pm 0.20$ \\
\hline 甲 & 87.74 & 3.86 & $16.32 \pm 0.10$ \\
\hline 日 & 86.69 & 2.79 & $16.82 \pm 0.14$ \\
\hline 因 & 88.78 & 4. 90 & $18.27 \pm 0.12$ \\
\hline 新 调 溥 & 88.38 & 4. 50 & $19.03 \pm 0.23$ \\
\hline 全＼cjkstart旦 & 88.87 & 4.99 & $21.60 \pm 0.12$ \\
\hline 相 平 & 89.80 & $5.9<$ & $23.85 \pm 0.13$ \\
\hline 岩手下開自 & 90.45 & 6.57 & $25.16 \pm 0.12$ \\
\hline 姶 自 & 73.97 & 9.91 & $37.85 \pm 1.37$ \\
\hline
\end{tabular}


で中等型を中心とした分布を示して括り，過 狭型，過広型は極めて少ない。

（5）形態顔面高

形態顔面高は顔面縦径を示す計測值である。 その測定法には 2 方法あるが，本調査では， Nasion と Gnathion との投射高を測定した。 本地方人の平均值は，121.02士0.24である。

（6）形態顔面指数

本指数は形態顔面高と顴骨乃幅との 比で岕 り, 顔面横径と緃待の関係を示すもので, 顔 型分類上重要な指数の 1 つである. 本地方の その平均値は 83.87 \pm 0.21 で示された。即ち本 地方のそれは小であることが分る。本指数に よる顔型分類で観察すると第 17 表の如くであ る。また，それを他地方人との型差でみると 第 18 表の如く，その親近度は信州安曇，能登 南部, 飛弾, 奥能登の諸地方が大であり, 姶 良, 岩手下閉伊, 相模平野, 庄内などの諸地 万は小である。

\section{V 平均型差による棕合比較}

前項までに個々の計測值及び指数值につい て人種学的な比較検討を実施したが，こ礼を 総括して各地方との近縁度を窺う必要がある。 人種的親疎の度合を示すには種々な方法が岁 るが，現在広く普及している方法は種族型差 である。それは著者が個々の計測値の他地方 との比較に用いたものである。元来型差は， Mollison により係数を50 として取扱つた。 その後 Poniatowsky により 便宜的に 係数は 100 と修正されたが，便に古屋は変異度で重 みづけをし，係数を10 として計測法の項で示 したT.D の方式を採用した。平均型差に対 しても, 古屋は変異係数に関係なしに, 単純 にそれを平均して，その平均型差を算出する ことを不合理と考光，それぞれの変異係数 (V) の逆数 (1/V) により重みづけを行い, そのうえで平均する方法を用いている，著者 もその方法により平均型差を算出し，綜合的 に他地方人との人種学的な比較を試みた。な
第 19 表 平均型差の熊野川流域地方の 比較

\begin{tabular}{|c|c|c|c|}
\hline \multirow{2}{*}{ 名 地人 } & 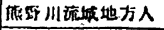 & \multirow{2}{*}{ 各 地 人 } & 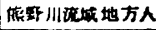 \\
\hline & $M T . D \pm m(M, T . D)$ & & MT $D \pm m$ (M.T.D) \\
\hline 但州管 & $3.18 \pm 1.37$ & 北理借州 & $6.67 \pm 1.24$ \\
\hline 俉州上伊那 & $4.14 \pm 1.64$ & 山形村山盒地 & $6.76 \pm 1.20$ \\
\hline & $4.25 \pm 1.23$ & 传州 钣田 & $6.81 \pm 3.28$ \\
\hline 埼王柬 仍 & $4.29 \pm 1.32$ & & $7.58 \pm 1.29$ \\
\hline 南 & 4. $33 \pm 1.18$ & 乘 & $7.59 \pm 1.09$ \\
\hline 馬 & $4.50 \pm 2.10$ & 加 山地 & $7.63 \pm 1.39$ \\
\hline E & $4.66 \pm 1.88$ & 能 軓 调 & $7.74 \pm 1.13$ \\
\hline \pm & $4.76 \pm 1.23$ & 带脆 & $7.99 \pm 1.22$ \\
\hline 向 & $5.00 \pm 1.23$ & 加资平地 & $8.03 \pm 1.06$ \\
\hline 姶 & $5.42 \pm 5.58$ & 新洞 酒 原 & 8. $78 \pm 1.42$ \\
\hline 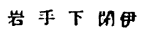 & $5.49 \pm 1.32$ & & $8.84 \pm 1.31$ \\
\hline$千$ 中 & $5.64 \pm 1.22$ & 生 & $8.91 \pm 1.22$ \\
\hline 梢 & $5.70 \pm 1.19$ & 相 平 政 & $9.74 \pm 1.35$ \\
\hline$F$ & $5.86 \pm 1.52$ & 因 & $10.43 \pm 1.25$ \\
\hline 婓 & $5.98 \pm 1.11$ & 越中（姆角） & $11.00 \pm 1.37$ \\
\hline 和 & $6.16 \pm 2.35$ & & $11.35 \pm 2.04$ \\
\hline 陪 & $6.22 \pm 2.07$ & 趣中（政波） & $11.66 \pm 1.65$ \\
\hline 蜜 & $6.42 \pm 1.38$ & 北海道フイ邓 & $12.99 \pm 1.66$ \\
\hline 抬 代 & $6.46 \pm 1.20$ & & \\
\hline
\end{tabular}

第 20 表 各地方人との近縁度一覧表

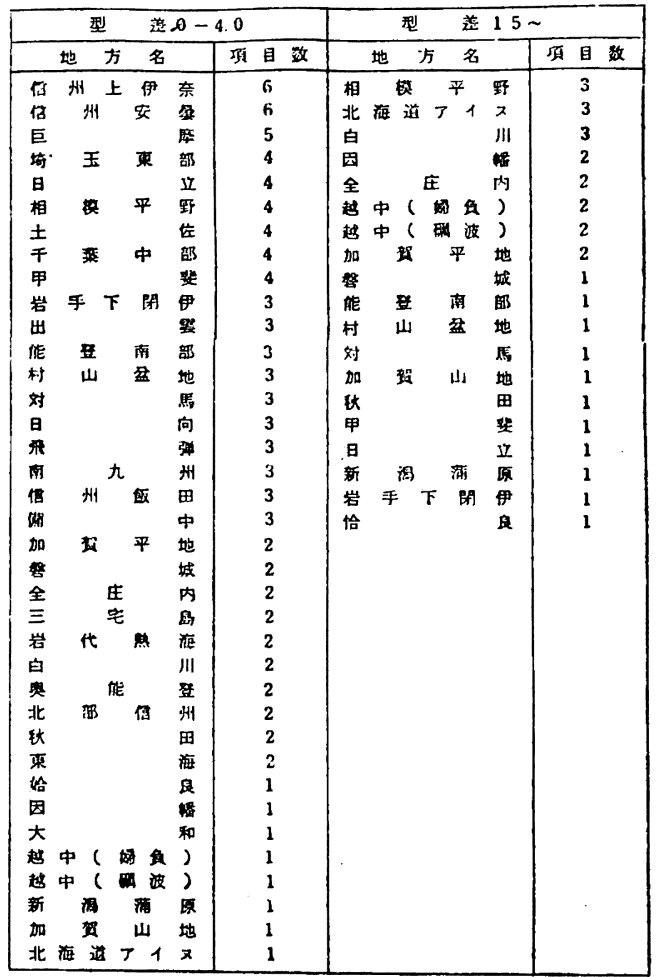


お，この場合平均型差は身長，頭最大長，頭 最大幅, 頭長幅指数耳頭高, 頭長耳頭高指数, 頭幅耳頭高指数, 形態顔面指数の 代表的 8 項 目についてのみ算出した。

各地方人との平均型差 7.0以下のものを親近 度が大, 12 以上のものは種族差異が極めて大 と認めて検討すると，第 19 表の如く信州安 量, 信州上伊奈, 飛弾, 埼玉東部, 南九州, 対馬,三宅島，土佐，日向などの諸地方は型 差 5 以下で比較的濃厚な 近緑関係が認められ るに反し, 北海道アイヌ, 越中 (碸波), 白 川, 越中 (婦負), 因幡の諸地方とは人種学的 親近度がうすいことが示される。

更に前紀の主要 8 項目の 各項目別の 型差に ついて，その型差 4 以下を親近度大, 15 以上 を親近度が小であると見做して，各地方別に それぞれの項目数を一括表示してみた。第 20 表にみられる如く，8 項目中型差 4 以下を最 ○多く有した地方は, 信州上伊奈, 信州安曇 の6項目であり，次では巨摩の 5 項目，埼玉 東部, 日立, 相模平野, 土佐, 千葉中部, 甲 婓の 4 項目などである。一方型差 15 以上が 3 項目ある地方は北海道アイス, 相模平野, 白 川の三地方人があげられる。

\section{VI 偏差折線による比較}

前項のような平均型差による種族比較は多 数の種族との近縁度を一数值で 表現し 得ると いう特徴を有している。しかし，個々の型差 の正負は無視されている．その欠点を補う意 味で Mollison による偏差折線図示法が考案 されている。それには，次の 3 種の方法が岁 る. 即ち偏差曲線法 $\left(\frac{\mathrm{M}_{1} \sim \mathrm{M}_{2}}{\sigma_{1}}\right)$, 偏差比曲 法 $\left(\frac{\mathrm{M}_{1} \sim \mathrm{M}_{2}}{\mathrm{~m}_{1}}\right)$, 型差曲線法 $\left(10\left(\mathrm{M}_{1} \sim \mathrm{M}_{2}\right)\right.$ $\left.\left(\frac{1}{\sigma_{1}}+\frac{1}{\sigma_{2}}\right)\right]$ の 方法がそれである.この うち型差曲線法は基礎種族とそれと比較され る種族とが互に变更しても絶対值が変らず, 正負逆となるだけで基線に 対称的な線を画く

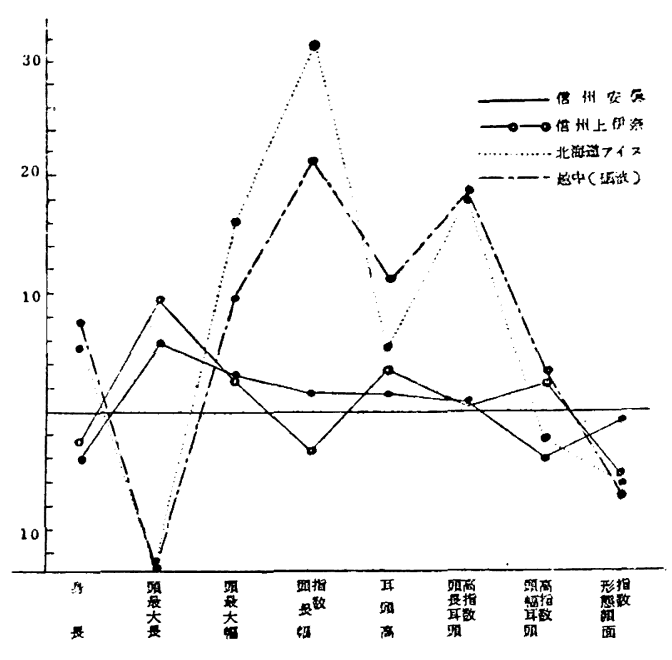

第2图型差 曲線

ために応用範囲も広い。これを用いて信州安 曇, 信州上伊奈, 北海道アイヌ, 越中（獂波） の諸地方と比較すれば第 2 図の如く，その正 負が明瞭に窺われる。

\section{诅 指数関係図示法による比較}

人種の親近度を比較する場合，個々の計測 値が大切であることは勿論でむるが，それら より算出される指数值も極めて重要である。

しかし, その指数值のみでは, その構成分子 を知ることが出来ないという欠点がある。そ れを補う意味で，指数值とその構成分子との 相互関倸を図示するるとにより人種学的な比 较検討を試みた。即ち頭長幅指数, 頭最大長, 頭最大幅の相互関係を図示した第 3 困がそれ である、頭型に扣いて本地方住民は対馬, 飛 弾，信州北部，日立などの住民に近似して特 り, 北海道フイヌ, 越中とは人種学的にかな り離れてることを示している。

\section{证 三角図示法による比較}

平圴型差, 偏差折線図示法, 指数関釈図示 法などにより他地方人との比較検討を実施し たが，相互間の関係をより一層明かにするた めに三角図示法による平均型差の 比較を試み 


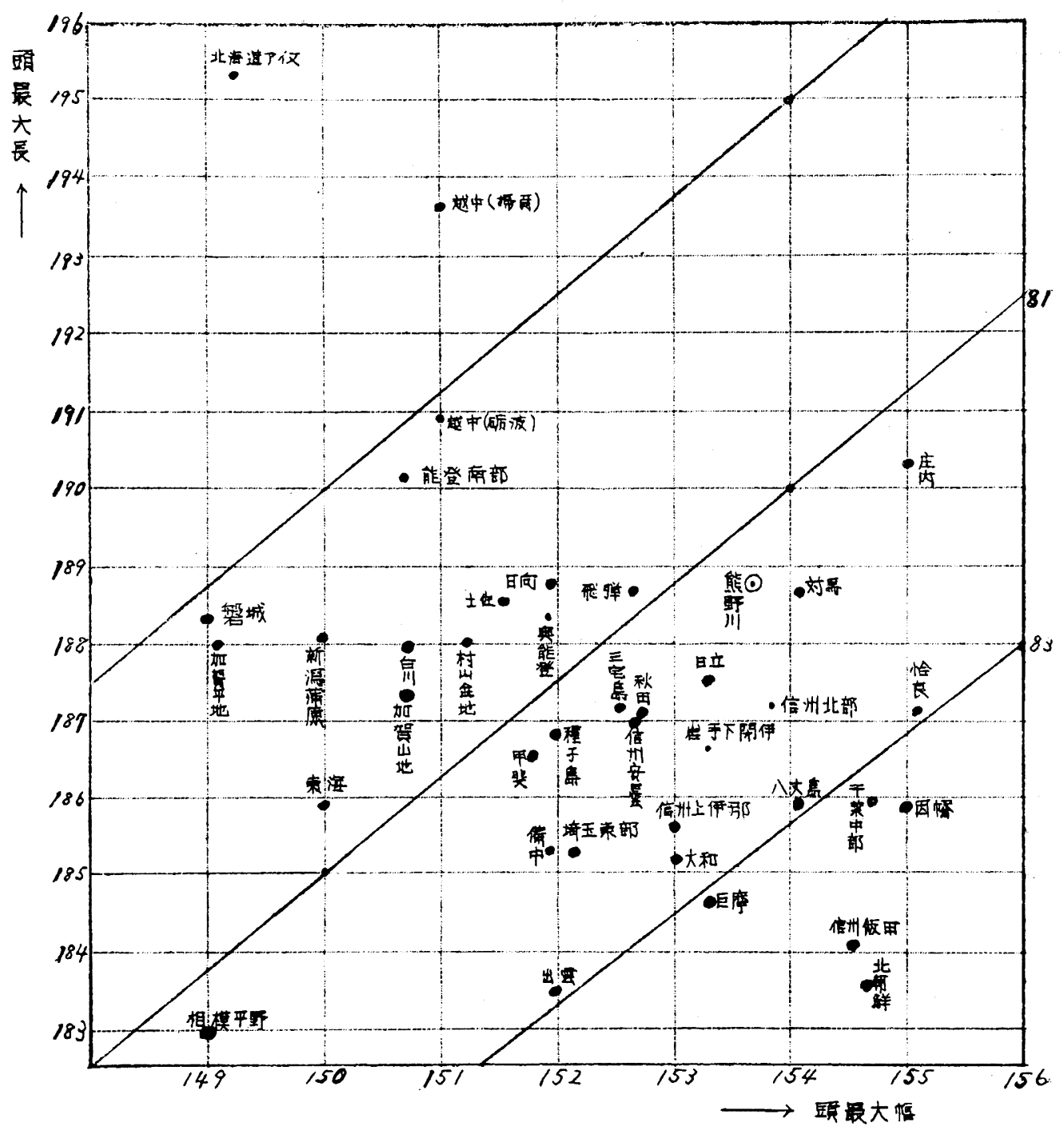

第 3 図頭長幅指数頭最大長䫓最大幅の関係図

た。これによつて第4 図に示されるように本 地方人と他地方人との近縁度をしるとともに， 信州安曇, 大利, 出雲の各地方人間の遠近も 図示される。

\section{む す び}

著者は昭和 32 年 10 月体質人類学的見地よ り熊野川上流域にある和歌山県東牟婁郡本宮 町及び熊野川町住民 528 名を対象として,衄幹
四肢，頭部及び顔面について生体測定を行い， 25 項目に亘る計测値，指数值に基ついて詳細. なる検討を加党，他地方人との比較分析を実 施した。

その成績を要約すれば下記の通りである。

(1) 本地方住民の平均身長は $160.52 \pm 0.26 \mathrm{~cm}$ であり，Martinの身長分類によれば「中の下」 に属するが，古屋一門によつて同様に計测さ 

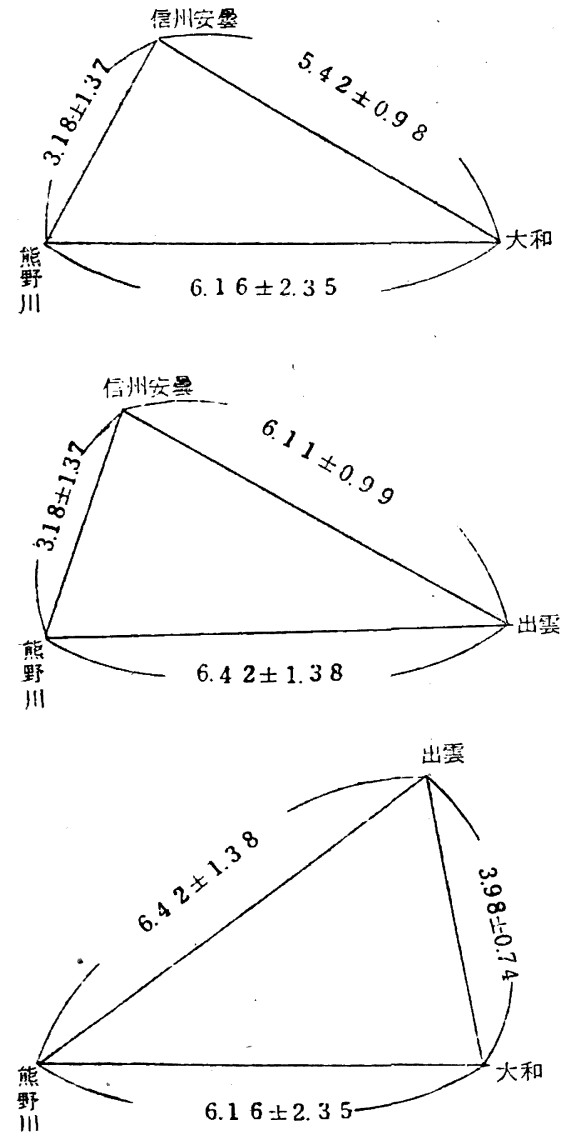

第 4 图三角形図示

れた各地方住民のそれと比較すると「中間」 に位する。また，型差からみると埼玉東部， 岩手下閉伊などの諸地方に近似している。

(2) 比上肢長は平均值 41.19士0.06 を示し, 短腕が過半数を占め, 他地方と比しかなり短 腕の比率は大となつている。

（3）頭最大長は平均 $188.83 \pm 0.30 \mathrm{~mm}$ で対 馬，日向，磐城の諸地方住民に近縁関係が認 められる．頭最大幅は $153.62 \pm 0.25 \mathrm{~mm}$ を示 し, 北部信州, 南九州, 岩手下閉伊の諸地方 々親近度が大である。

（4）頭長幅指数はその 平均値 81.84士0.22で ある、それを Martin の頭型分類，或は指数 関倸図示法でみると稍短頭の傾向を示して拉 り対馬, 北部信州, 飛弾などの諸地方と近似
している。

(5) 耳頭高は $127.67 \pm 0.39 \mathrm{~mm}$ で信州飯田, 巨摩，東海などと近縁関係があることが窥わ れた。

(6) 頭長耳頭高指数は 68.22士0.22を示し, それを Martin-Saller の頭型分類よりみれば， 85\% が高頭型に属して扮り，信州上伊奈，信 州安曇の諸地方と近い。

(7) 頭幅耳頭高 指数は平均值 83.33土0.25 で 甲斐, 越中 (婦負), 巨摩の諸地方とその人種 近縁度が大である。

（8）顴骨弓幅は本地方住民の平均値 144.29土 0.23 を示し，顴骨 弓幅下顴角幅 指数は平均 $77.54 \pm 0.15$ で，顏型分類からみると中等型を 中心とした分布をなしている。

（9）形態顔面指数は, その平均值 $83.87 \pm 0.21$ と比較的低い值を示している. 顔型分類から のその分布状況は村山盈地人に近似して招り， その型美からみると, 信州安是, 熊登南部, 飛弾，奥能登，村山盈地などと親近度が 深い ことが窥われた。

(10) 本地方住民と他地方住民との人種的親近 度を単に個々の計測值，指数值で比較するだ けではなく，それらのうち重要8項目につい て平均型差を求めて綜合的な比較を実施した。 平均型差の一番小さいのは信州安量の 3.18 で あり, 次いで信州上伊奈, 飛弾, 埼玉東部, 南九州, 対馬, 三宅島，土佐，日向などの諸 地方が型差 5 以下で濃厚な種族的近親度を示 している。一方, 親近度の低い地方としては 北海道アイヌの 12.99 を始めとして越中（喏 波)，白川，越中（婦負），因幡の諸地法が型 差 10 以上を示した。

(11) 偏差折線法, 指数関倸図示法, 三角図示 法などによつての比較検討に於ても，平均型 差で得た結果と略類似の傾向を指摘し得た。

稿を終るに臨み，終始後指導，御校閲を賜つ た恩師古屋芳婎教授に深甚なる謝意を表すとと もに，種々御懇切な御教示を賜つた乗木秀夫教 授及び調查に御協力頂いた杉木斉助教授を始め 
㵝生学教室員各位に感謝致します。

\section{参考 文 献}

1) Martin, R.: Lehrbuch der Anthropologie Anfl, 2 (1928)

2) 古屋芳雄：医学統計法 (1955)

3）清野㗝次，金閣文夫：人種起原説 (1928)

4）安田徳太郎：人間の歴史, 1〜3 巻 (1952-53)

5) 松岡寿人：現代人類問題研究 (1935)

6) 村田四郎：民族生物学研究，第 2 輯 (1936)

7) 村田四郎：民族生物学研究, 第 3 輯 (1937)

8）古屋芳雄他：民族生物学研究，第 4 輯 (1937)

9) 加藤義治郎：民族生物学研究，第 5 輯 (1938)

10）加藤莪治郎：民族生物学研究, 第6 輯 (1939)

11）熊沢清志：大和人, 出雲人の体質人類学的研 究 (厚生科学研究) (1942)

12）上田栄吉：土佐人の 体質人類学的研究（未発 表)

13）古屋芳雄：日向人の体質人類学的研究（未発 表)

14）古屋芳雄： Rassen Kunde der Aino (1937)
15）大森暢久：日医大誌，第 17 巻 6 号 (1950)

16）高野武悦：信州医学雑誌, 第 3 巻 1 号 (1954);

17）西村茂一：日医大誌，第 22 卷 2 号 (1955)

18）村松 稳：民族䰜生，第 22 巻 5.6 号 (1954)

19）湯浅 秀：日医大誌，第 21 巻 11 号 (1954)

20）山崎倫子：日医大誌，第 22 巻 11 号 (1955)

21）宮坂五一郎：民族鬲生，第 22 巻 4 号 (1956)

22）津村大八：民族衙生，第 25 巻 4 号 (1959)

23）矢ケ崎淳一：民族衙生，第 25 巻 4 号 (1959)

24）鈴木康弘：民族荏生，第 25 巻 3 号 (1959)

25）隈本康：民族衙生，第 25 巻 4 号 (1959)

26）安方魅人：日医大誌，第 23 巻 4 号 (1956)

27）荻野 博：日医大誌，第 23 巻 12 号 (1956)

28）岡部五成：民族衙生，第 25 巻 2 号 (1959)

29）藤井章：民族耐生，第 25 巻 2 号 (1959)

30）津村大輔：民族峏生，第 26 巻 2 号 (1960)

31）山田幸一：民族衙生，第 26 巻 1 号 (1960)

32) 宮坂勝蔵: 日医大誌, 第 24 巻,7号 (1957)

33) 斎藤達郎：民族耎生，第 25 巻 5 号 (1959) 
A Constitutional-anthropological Study of the Inhabitants of the Valley of the Kumano River

By

\section{Masayoshi MATSUMORI}

The writer made a biometric measurement of bodies, heads and faces for 528 . adult inhabitants of Hongu-machi and Kumanogawa-machi situated in the valley of the upper course of the Kumano River, Wakayama perfecture, from the constitutional-anthropological point of view, in October, 1957. The summarized findings through the detailed examination on measurements and indices over 25 items are as follows:

1. The average height of the inhabitants is $160.52 \pm 0.26 \mathrm{~cm}$ which belongs to. "short-medium height" by Mr. Martin's classification and to "medium height" by Prof. Koya and his group. It is a similar type to those of the eastern part of Saitama prefecture and Shimoheii district, Iwate prefecture.

2. The average comparative-length of the upper limbs is $41.19 \pm 0.06$. Over half of all, the higher ratio than other districts, belong to the "short arm" class.

3. The maximum length of head is $188.83 \pm 0.30 \mathrm{~mm}$ which is similar to the inhabitants of Hiuga and Iwaki. The maximum breadth of head is $153.62 \pm 0.25 \mathrm{~mm}$ which is. similar to those Northern Shinshu, Southern Kyushu and Shimoheii district, Iwate prefecture. The average index number of length-breadth of head is $81.84 \pm 0.22$ which: belongs to "short bead-length" by Martin's classification and is similar to the inhabitants of Tsushima island, Northern Shinshu and Hida.

4. The breadth of zygomatic arch is $144.29 \pm 0.23 \mathrm{~mm}$ and the index of zygomatic arch is 77.54 0.15 . Many of the facial types here belong to the middle type of the face classification.

5. The average number of the morphological face index is $83.87+0.21 \mathrm{~mm}$ which is relatively low. The distribution of the face classification is similar to that of inhabitants of Murayama basin. The close similarity in the type difference is seen with: Shinshu Azumi, Southern part of Noto Peninsula, Hida, Oku Noto and Murayamae. basin.

(From the Department of Hygiene, Nippon

Medical College, Tokyo) 